\title{
Anticysticercous antibodies in serum and cerebrospinal fluid in patients with cerebral cysticercosis
}

\author{
TERESA CORONA,* DALILA PASCOE, $†$ DOLORES GONZÁLEZ-BARRANCO, \\ PATRICIO ABAD,* LUIS LANDA, $\dagger$ BRUNO ESTAÑOL*
}

From the Department of Neurology, ${ }^{*}$ and the Division of Research in GI Diseases, $\dagger$ Hospital General, Centro Médico Nacional, and the Division of Research Hospital General de México, $\ddagger$ Mexico

SUMMARY Fifty-one cases of cerebral cysticercosis proved by surgery or CT scanning were studied prospectively with the ELISA test in order to detect anticysticercous antibodies in blood and CSF. The ELISA test was also performed for detection of antibodies in 20 control patients who had CSF withdrawn during a myelogram and in 119 serum samples of asymptomatic subjects. We found an overall sensitivity of the ELISA test in the blood of $87 \%$ with a specificity of $90 \%$. In the CSF we found a sensitivity of $87 \%$ with a specificity of $100 \%$. However, when we compared patients with cerebral cysticercosis of a benign type with patients with cerebral cysticercosis of a malignant type we found a serum sensitivity of $75 \%$ for the benign group as compared to $93 \%$ of the malignant group. The CSF sensitivity was $80 \%$ in the benign group and $93 \%$ in the malignant group. This difference was statistically significant.

Cerebral cysticercosis is a highly heterogeneous and complex disease from the clinical and pathogenetic viewpoints. ${ }^{12}$ It may be an asymptomatic or "silent" infestation or it may cause death or serious sequelae..$^{3-6}$ In post-mortem studies performed in Mexico City, it has been found that approximately $3 \%$ of the population coming to necropsy has cerebral cysticercosis. Nevertheless, most of the patients who were found to have cysticerci in the brain were asymptomatic. Only in $20 \%$ of the cases was the parasitic infestation directly responsible for the death of the patient; in the remaining $80 \%$ the parasite was an incidental finding. ${ }^{57}$

The patients who were asymptomatic had parenchymal or calcified parasites, whereas all the patients who died as the consequence of the infestation had hydrocephalus. ${ }^{7}$ In India it has long been known that cerebral cysticercosis may be a "silent" infection with few or absent clinical symptoms or it may be a severe illness causing death or incapacitating sequelae. ${ }^{45}$ More recently, the natural history of parenchymal

Address for reprint requests: Professor Bruno Estañol, Hospital Santelena, Quaretaro 58, Planta Baza, Col Roma, 06700 Mexico DF, Mexico.

Received 16 July 1985 and in revised form 9 December 1985. Accepted 15 December 1985 cerebral cysticercosis was evaluated in 73 MexicanAmerican patients living in Los Angeles. ${ }^{38}$ In this population it appears to be a relatively benign disease. The diagnosis was incidental in $20 \%$ of the cases and the main problems were seizures. Surgery was performed in only $6 \%$ of the cases and only for diagnostic confirmation; the main clinical problem was seizure control. These studies suggest that parenchymal cysts and calcified parasites are well tolerated by the host. On the other hand patients with hydrocephalus due either to ventricular cysts or basal meningitis fare poorly despite shunting procedures. We have recently attempted to classify cerebral cysticercosis into benign and malignant forms according to the clinical symptoms and natural history of the disease. ${ }^{9}$ We found that the following forms of cerebral cysticercosis had a benign course with little or no symptoms: (a) parenchymal cysts; (b) calcified forms; (c) combination of parenchymal cysts and calcification. These patients were either asymptomatic or had seizures as the sole manifestation of the infestation. The patients who had a malignant course were highly symptomatic with raised intracranial pressure, seizures, mental changes, gait apraxia, cranial nerve palsies and stroke. We classified under malignant form the following types: (1) hydrocephalus either due to intraventricular cysts or basal meningitis; (2) 
vasculitis and cerebral infarction; (3) multiple granulomata (cysticercous encephalitis); (4) giant supraventricular cysts. On the other hand, anticysticercous antibodies, measured by various techniques (indirect haemagglutination, immunoelectrophoresis, indirect immunofluorescence, complement fixation tests) have been demonstrated between 60 and $80 \%$ of the patients with proven cerebral cysticercosis ${ }^{10-16} \mathrm{We}$ thought that a correlation between the type of cerebral cysticercosis and level of serum and CSF antibodies would be present if an immune mechanism was important in the pathogenesis of the cerebral damage and might help in understanding of the low sensitivity of the serologic tests used in the diagnosis of cerebral cysticercosis. ${ }^{17}$

We postulated that the sensitivity of the ELISA test for detection of anticysticercous antibodies in serum and CSF was lower in patients with a benign course than in those with a malignant course. In addition, if the humoral response was involved in the pathogenesis of the symptoms the antibody titres would be higher in the malignant form as compared to those with a benign course. We also studied the serum and CSF of patients with cerebral cysticercosis in order to have a control population, thought to be necessary in an endemic region.

\section{Patients and methods}

We prospectively studied over two years, 51 patients in whom the diagnosis of cerebral cysticercosis was established either by surgery or by CT scanning. Patients in whom the diagnosis of cerebral cysticercosis was in doubt or had hydrocephalus of other types were excluded. The mean age of the patients was 38 years, with a range 18 to 61 years; 27 patients were male and 24 were female. Twenty patients had parenchymal cysts or calcification or a combination of both. These patients had a benign course and were diagnosed by CT scanning. The presenting complaints were headache or seizures (table 1). Thirty-one patients had hydrocephalus, giant supratentorial cysts, cerebral infarction or cysticercous encephalitis. These last patients had raised intracranial pressure with papilloedema, gait difficulties, cranial nerve palsies, mental changes, disturbance of consciousness and seizures. These patients had a malignant course (table 2).

All the hydrocephalus patients underwent a ventriculoperitoneal shunt. Eleven out of the 21 patients with hydrocephalus underwent surgical removal of the intraventricular cyst. The three patients with giant cysts in the supratentorial space all were operated. Twenty-nine out of the 31 patients with malignant cysticercosis underwent a surgical procedure. The control groups were 119 asymptomatic subjects without a history of a neurological disease from whom we obtained a blood sample. We also studied 20 CSF samples in 20 patients who underwent a spinal tap for a myelogram due to a herniated lumbar disc. Patients with neurological dis-

Table 1 Benign cerebral cysticercosis (20 patients)

\begin{tabular}{|c|c|c|}
\hline & Number & Symptoms \\
\hline 1. Patients with parenchymal cysts & $9(45 \%)$ & $\begin{array}{l}\text { Asymptomatic } 1 / 9 \\
\text { Seizures } 4 / 9 \\
\text { Headache } 4 / 9\end{array}$ \\
\hline 2. Patients with calcified parasites & $2(10 \%)$ & $\begin{array}{l}\text { Headache } 1 / 2 \\
\text { Seizures } 1 / 2\end{array}$ \\
\hline $\begin{array}{l}\text { 3. Patients with parenchymal cysts and } \\
\text { calcified parasites }\end{array}$ & $3(15 \%)$ & $\begin{array}{l}\text { Asymptomatic } 2 / 3 \\
\text { Seizures } 1 / 3\end{array}$ \\
\hline 4. Patients with granulomata & $2(10 \%)$ & $\begin{array}{l}\text { Headache } 1 / 2 \\
\text { Seizures } 1 / 2\end{array}$ \\
\hline $\begin{array}{l}\text { 5. Patients with parenchymal cysts and } \\
\text { granulomata }\end{array}$ & $4(20 \%)$ & $\begin{array}{l}\text { Headache 2/4 } \\
\text { Seizures 2/4 }\end{array}$ \\
\hline
\end{tabular}

Table 2 Malignant cerebral cysticercosis (31 patients)

\begin{tabular}{|c|c|c|}
\hline & Number & Symptoms \\
\hline 1. Patients with hydrocephalus & $26(83 \cdot 8 \%)$ & $\begin{array}{l}\text { Increased intracranial pressure, mental } \\
\text { changes, gait difficulties, cranial nerve } \\
\text { palsies, seizures }\end{array}$ \\
\hline $\begin{array}{l}\text { 2. Patients with hydrocephalus secondary } \\
\text { to subarachnoid blockage }\end{array}$ & $15(48 \cdot 3 \%)$ & $\begin{array}{l}\text { Increased intracranial pressure, mental } \\
\text { changes, gait difficulties, cranial nerve } \\
\text { palsies, seizures }\end{array}$ \\
\hline 3. Patients with intraventricular cysts & $11(35 \cdot 4 \%)$ & $\begin{array}{l}\text { Increased intracranial pressure, gait } \\
\text { difficulties, mental changes, cranial } \\
\text { nerve palsies }\end{array}$ \\
\hline 4. Patients with giant supratentorial cysts & $3(9 \cdot 6 \%)$ & $\begin{array}{l}\text { Increased intracranial pressure, mental } \\
\text { changes, hemispheral lesion }\end{array}$ \\
\hline 5. Patients with cysticercous encephalitis & $1(3 \cdot 2 \%)$ & $\begin{array}{l}\text { Increased intracranial pressure, diffuse } \\
\text { encephalopathy }\end{array}$ \\
\hline 6. Patients with vasculitis & $1(3 \cdot 2 \%)$ & Stroke \\
\hline
\end{tabular}


eases other than cerebral cysticercosis were excluded.

Antigen preparation We followed the method of Kagan $^{13}{ }^{18}$ with some modifications. The cysticerci were obtained from parasitised pig's meat. The parasites were washed in saline solution, frozen and unfrozen three times; afterwards they were sonicated for 5 minutes in an ice bath, then they were lyofilised and crushed in a mortar; thereafter they were hydrated in a coca solution and centrifugated for 30 minutes at 3500 RPM (centrifuge WIFV 6). The supernatant was dialysed against saline solution. The dyalisate was again centrifugated and the proteins were quantified. Finally it was lyofilised again and stored.

ELISA test Dynatech Immulon plates with removable wells were used in this study. The technique was as follows: $200 \mathrm{mcl}$ of cysticercous cellulosa antigen in a concentration of $5 \mathrm{mcg} / \mathrm{ml}$ for the serum test and $3 \mathrm{mcg} / \mathrm{ml}$ for the CSF test for each well was kept at $4^{\circ} \mathrm{C}$ for 12 hours. To it was added $200 \mathrm{mcl}$ of serum or CSF diluted 1:200 for the serum in PBs tween and 1:10 for the CSF also in PBs tween. Then, it was incubated for 30 minutes at $37^{\circ} \mathrm{C}$ and then washed for five minutes three times. Anti IgG $(200 \mathrm{mcl})$ was added to each well. After again washing for five minutes each well received $200 \mathrm{mcl}$ of substrate solution and was incubated for 30 minutes at $37^{\circ} \mathrm{C}$. Finally the reaction was stopped with $50 \mathrm{mcl}$ of $\mathrm{NaOH}_{2}$ solution in a normal concentration and the reading was made of optic densities in a microlector for ELISA 810-C titertek-multiskar. The technique is the indirect ELISA test.

Statistical treatment The $U$ test of Mann Whitney was used to compare the values of optical densities between the serum and CSF of patients and controls and between patients with cerebral cysticercosis of benign and malignant types. The percentages of positivity and negativity were compared between patients with benign and malignant cysticercosis using the exact probability test of Fisher. The value of optic density considered to be positive was the mean plus one standard deviation of the control population. The non parametric $U$ test of Mann Whitney was used because the distribution of the data was not normal.

\section{Results}

In figs 1 and 2 the level of antibodies in optical densities (OD) by the ELISA method in patients with proven cerebral cysticercosis and controls is shown. The mean of optic densities in serum and CSF for patients with proven cerebral cysticercosis was 0.939 \pm 0.576 and $0.906 \pm 0.692$ respectively.

The control patients had a mean of $0.306 \pm 0.137$ in serum and in CSF of $0 \cdot 20 \pm 0 \cdot 024$. Figures 3 and

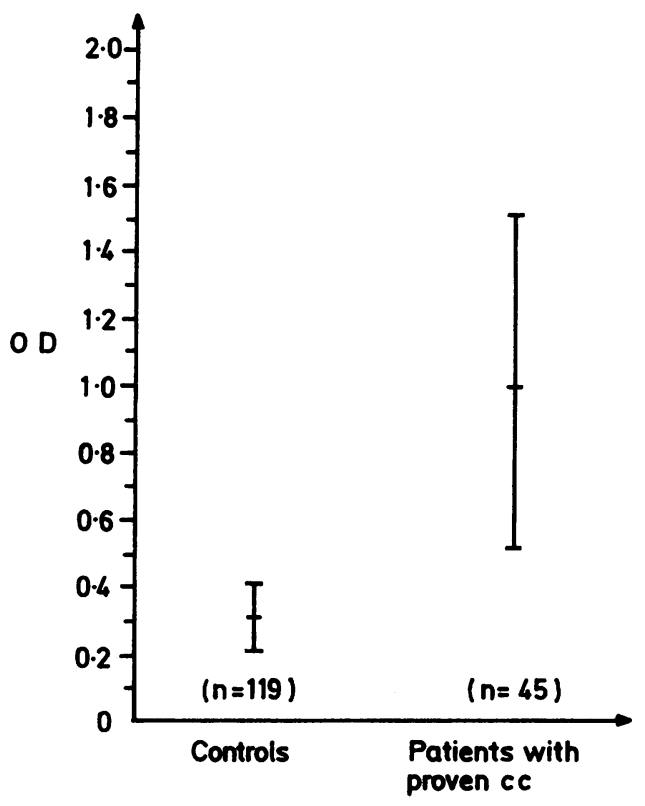

Fig 1 Levels of antibodies in optical densities by ELISA in patients with proven cysticercosis and controls, in serum.

4 show the results of ELISA in patients with benign and malignant cerebral cysticercosis. In the patients with benign cerebral cysticercosis the mean OD in serum was 0.87 and in CSF was 0.724 . In contrast in the patients with malignant cerebral cysticercosis the mean in serum was 1.162 and 1.452 in CSF. The difference between the patients with benign and malignant cerebral cysticercosis was found to be highly significant $(p<0.01)$ in serum and CSF.

The sensitivity of the ELISA test in patients with proven cerebral cysticercosis in serum was $87 \%$ with a specificity of $90 \%$. In the CSF the sensitivity was $88 \%$ with a specificity of $100 \%$.

In the serum the mean level of optical densities of the ELISA test were 0.87 and 1.162 for the benign and malignant forms respectively. This difference is highly

Table 3 Comparison of the sensitivity of the ELISA in patients with benign and malignant cerebral cysticercosis

\begin{tabular}{llc}
\hline & Sensitivity \\
\hline 1. Patients with benign cerebral cysticercosis serum & $75 \%$ & p $<0.01$ \\
2. Patients with malignant cerebral cysticercosis serum & $93 \%$ & (Exact probability test of Fisher) \\
3. Patients with benign cerebral cysticercosis CSF & $80 \%$ & p 0.01 \\
4. Patients with malignant cerebral cysticercosis CSF & $93 \%$ & (Exact probability test of Fisher) \\
\hline
\end{tabular}




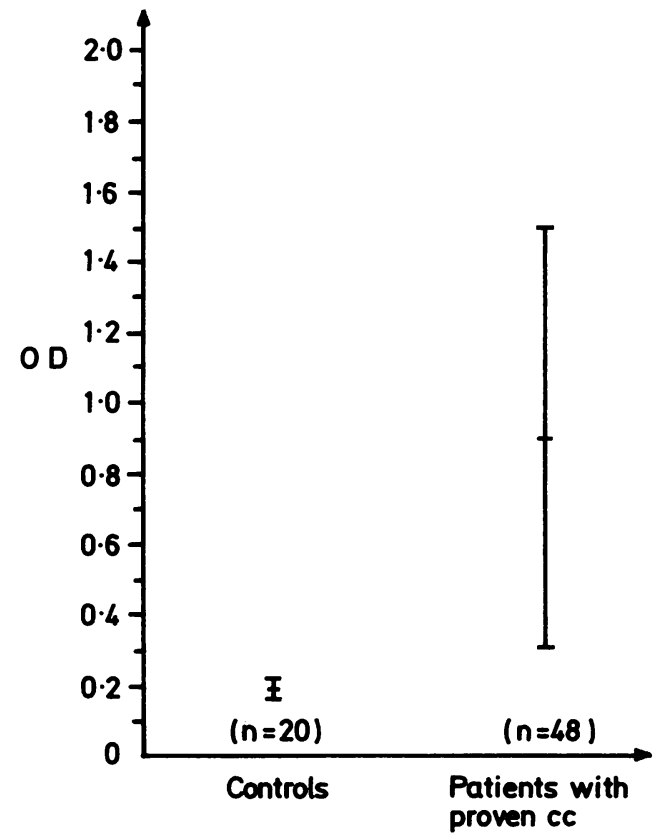

Fig 2 Levels of antibodies in optical densities (OD) by ELISA in patients with proven cysticercosis and controls, in $C S F$.

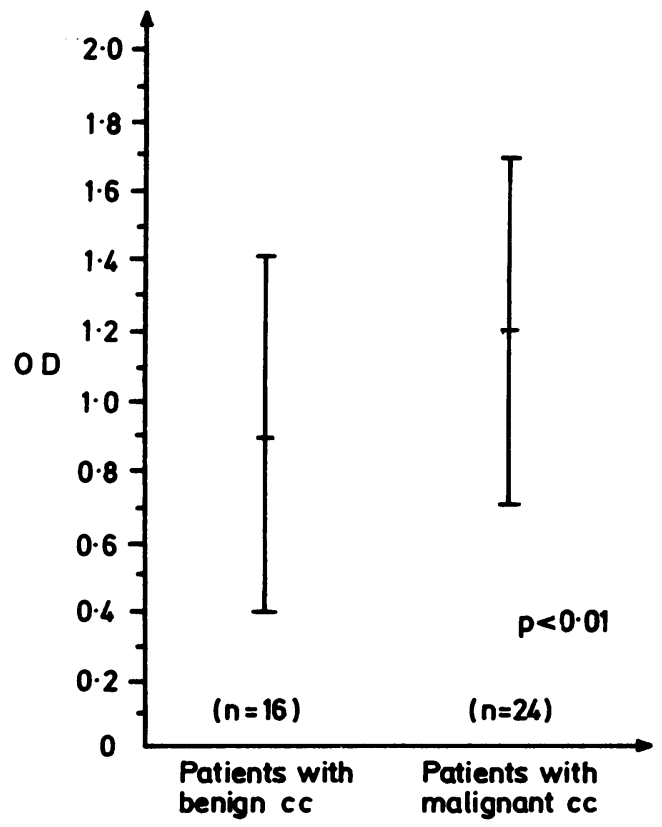

Fig 3 Results of ELISA in patients with benign and malignant cysticercosis (cc) in serum.

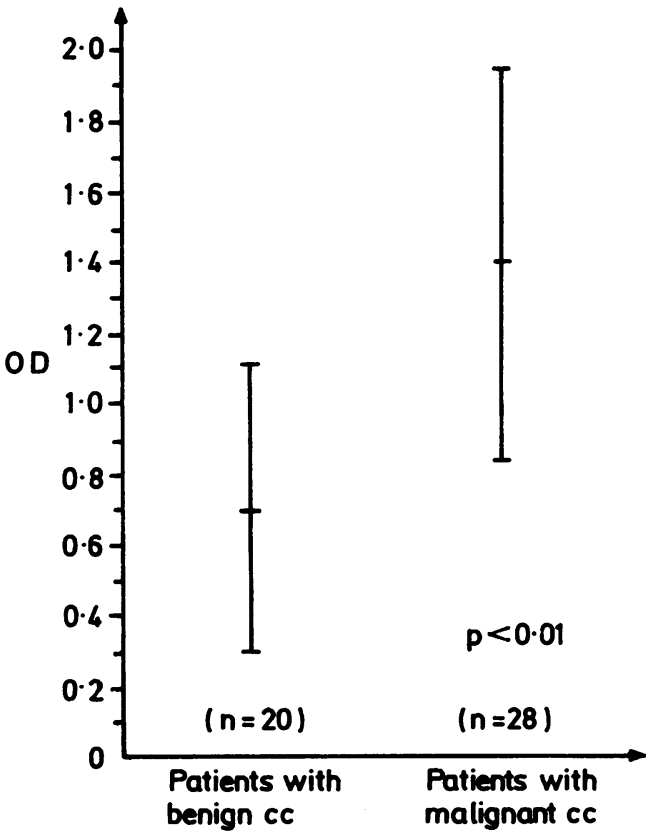

Fig 4 Results of ELISA in patients with benign and malignant cysticercosis, in CSF.

significant statistically $(\mathrm{p}<0.01)$. In the CSF the mean of the OD was 0.724 for the benign group and 1.452 for the malignant group $(\mathrm{p}<0.001)$. The difference in sensitivity of the test in the serum was $75 \%$ for the benign group and $93 \%$ for the malignant group $(p<0.01)$. The optical densities in the group of patients with malignant cysticercosis in the serum was 1.162 and in the CSF 1.452 . This difference was found also significant statistically $(p<0.01)$ (table 3 ).

\section{Discussion}

Our data show that cerebral cysticercosis is a complex and pleomorphic infection from the clinical and immunological points of view; this study also throws some light on the understanding of the pathogenesis of the symptoms and its relationship with the humoral response in cerebral cysticercosis.

Patients with benign cerebral cysticercosis have a low level of antibodies in serum and CSF. The sensitivity in the serum in patients with benign cysticercosis was $75 \%$, whereas the sensitivity in the serum in patients with malignant cysticercosis was $93 \%$. The sensitivity of the test in the CSF was $80 \%$ in the patients with benign cerebral cysticercosis as compared with $93 \%$ of the patients with malignant 
cerebral cysticercosis. The difference in sensitivity in serum and CSF between the patients with benign and malignant cerebral cysticercosis is highly significant $(p<0.01)$. This difference persists even if we compare the absolute values of the optical densities of the ELISA test in both groups of patients. The ELISA test had an overall sensitivity in the serum of patients with proven cerebral cysticercosis of $87 \%$ and a specificity of $90 \%$. The specificity in the CSF was $88 \%$. This study suggests that the low sensitivity of the serologic tests previously reported was due to the fact that we were sampling two different populations of patients with cerebral cysticercosis. ${ }^{17}$ 19-24

Our data demonstrate that patients with malignant cerebral cysticercosis have a much more marked humoral response than those with a benign course. It also suggests that the cerebral damage may be partially mediated by the immune response. The lack of production of antibodies in cerebral cysticercosis has been perplexing. In the past it has been attributed to: (1) variable antigenicity of Cysticercus cellulosae; (2) "evasion" of the parasite by covering itself with immunoproteins of the host; (3) "suppression" of the humoral immune response by the parasite; (4) immune suppression by ingestion of steroids; (5) technical defects in the tests and in the preparation of the antigen. ${ }^{25-30}$ We carefully looked for the ingestion of steroids in both groups of patients. Only $10 \%$ of the patients with a benign course had taken steroids sometime during the course of their illness, and this factor cannot account for the low sensitivity of the tests in this group. On the other hand almost $75 \%$ of the patients with malignant cerebral cysticercosis received steroids. We examined the patients with negative serology searching for causes to explain the negativity of the ELISA test in patients with proven cysticercosis of a malignant type. The two patients with humoral response had received large amounts of intravenous steroids for at least two weeks preceding the determination of serum and CSF antibodies. Nevertheless the steroid intake could not be the sole factor in the lack of antibody response as $75 \%$ of the patients with cerebral cysticercosis of the malignant type had steroid therapy.

The patients with malignant types who did not have a humoral response had large cysts in the supratentorial space. We concluded that some patients with cerebral cysticercosis do not produce antibodies and patients with cerebral cysticercosis of a benign nature are non responders in a greater proportion of cases. The reason why some patients do not produce antibodies should be sought in the complex relation of host and parasite. This relationship also determines the production of symptoms. It is clear that the parasite may be present in the brain without the production of disease. ${ }^{4}$ The parasite may produce symptoms by mechanical compression or obstruction or by the induction of an inflammatory process surrounding the parasite. ${ }^{931}$ Intraventricular cysts may produce obstruction to the CSF circulation that may prove fatal to the patient with little or no inflammation. ${ }^{7}$ A giant cyst in the supratentorial space may also compress the cerebral tissue and induce mechanical damage with scant inflammation. Cysticercus cellulosae in the parenchymal tissue is remarkably well tolerated and the inflammatory reaction is sparse around these lesions. ${ }^{7}$ In contrast, the inflammatory reaction is intense around Cysticercus racemosus $;$ it is also severe in arachnoid reactions in the cisterns surrounding the brain stem, the chiasm and Sylvian subarachnoid spaces. ${ }^{7}$ The symptoms are also produced by the presence of an inflammatory reaction in patients with vasculitis, multiple granulomata and ependymitis. ${ }^{9}$ The calcification is not associated with an inflammatory process. ${ }^{7}$

We found that the sensitivity of the ELISA test in patients with benign cerebral cysticercosis was the same in both serum and CSF, and the titre of antibodies was low in both. In contrast, the amount of anticysticercous antibodies in the CSF in patients with malignant cerebral cysticercosis was much higher than the serum. This difference was also statistically significant $(p<0.01)$. These findings suggest de novo synthesis of anticysticercous antibodies inside the central nervous system and it also indicates that the inflammatory reaction in the central nervous system may be mediated by the humoral immune response. Alternatively, the patients with malignant cysticercosis may have a more severe dysfunction of the blood brain barrier and the higher titre of antibodies indicate a greater passage of antibodies from the blood to the brain. We believe this is unlikely because the mean optical densities in the CSF were much greater than the mean optical density in the serum in patients with malignant disease. The natural history, clinical findings, pathological evidence and humoral immune response suggest that parenchymal cysticercosis alone or in combination with calcification is a benign problem that is largely asymptomatic or presents with seizures or headaches. These patients have a lower percentage of positivity for the presence of anticysticercous antibodies, if they are present. The infection seems compatible with a normal life expectancy and pathologically there is sparse inflammation in the cerebral tissue surrounding the parasite. ${ }^{7}$ In contrast, patients with malignant cysticercosis have an illness that may progress and lead to death or incapacitating sequelae. The titre of anticysticercous antibodies in this group of patients is much higher than in the benign group suggesting that the inflammatory process is to a great extent mediated by the humoral response. 
Patients with intraventricular and large supratentorial cysts have increased intracranial pressure and have a life-threatening illness but the main mechanism of cerebral damage is mechanical compression or obstruction to the CSF circulation and probably not the production of an inflammatory process. $^{31}$ These patients, therefore may have lower titres of antibodies as compared to those patients with hydrocephalus due to basal arachnoiditis, vasculitis or multiple granulomata. Further studies correlating antibody levels, amounts of immunoglobulins, presence of immune complexes, sub-populations of $\mathrm{T}$ and $\mathrm{B}$ lymphocytes in the CSF of patients with cysticercosis of a benign and malignant course are urgently needed.

\section{References}

${ }^{1}$ Mateos JH. Cisticercosis cerebral como problema de salud pública. Gaceta Médica de México 1972;103:225-50.

${ }^{2}$ Lombardo L, Mateos JH. Cerebral cysticercosis in Mexico. Neurol 1961;11:824-8.

${ }^{3}$ Gardner B, Goldber M, Heiner D. The natural history of parenchymal central nervous system cysticercosis. Neurology 1984;34(Suppl 1):90.

${ }^{4}$ Showramma A, Reddy DB. Silent cysticercosis of the brain. An analysis of five cases with special reference to histopathology. Indian J Pathol Bacteriol 1963;6:142-7.

${ }^{5}$ Bhaskaran CS. Cerebral cysticercosis as a cause of unnatural deaths. Indian J Med Sci 1973;27:545-7.

${ }^{6}$ Miller B, Grinnell V, Goldberg MA, Heiner D. Spontaneous radiographic disappearance of cerebral cysticercosis: three cases. Neurology 1983;33:1377-9.

${ }^{7}$ Rabiela MT, Rivas MA, Rodriguez IF. Consideraciones anatomopatológicas sobre cisticercosis cerebral coma causa de muerte. Patol Mex 1979;17:119-36.

${ }^{8}$ Powell SJ, Proctor EM, Wilmot AJ, Macleod IN. Cysticercosis and epilepsy in Africans: a clinical and serological study. Ann Trop Med Parasitol 1966;60:152-8.

${ }^{9}$ Estañol B, Corona T, Abad P. Clasificación pronóstica de la cisticercosis cerebral. Implicaciones terapéuticas. Gaceta Médica de México (in press).

${ }^{10}$ Mahajan R, Chpova J, Chitkara L. Comparative evaluation of indirect hemagglutination and complement fixation tests in serodiagnosis of cysticercosis. Indian $J$ Med Res 1979;63:121.

${ }^{11}$ Nieto D. Cysticercosis of the nervous system: diagnosis by means of the spinal fluid complement fixation test. Neurology 1956;6:725-38.

12 Villanueva DG, Gonzalez BD. Aplicación de la prueba de hemagglutinación indirecta en la cisticercosis humana. Rev Méd Hosp Gral 1980;43:253-6.

${ }^{13}$ Gonzalez BD. Reacción de inmunofluorescencia indirecta en cisticercosis. Archivos Invest Med 1978;9:51-8.
${ }^{14}$ Espinoza B, Flisser A, Plancarte A, Larralde C. Immunodiagnosis of human cysticercosis: ELISA and immunoelectrophoresis. In: Flisser A, Willms K, Laclete JP, Larralde C, Ridaura C, Beltran F, eds. Cysticercosis: Present State of Knowledge and Perspectives. New York: Academic Press, 1982:163-70.

${ }^{15}$ Flisser A, Tarrab R, Willms $\mathrm{K}$, Larralde $\mathrm{C}$. Inmunoelectroforesis y doble inmunodifusión en el diagnóstico de la cisticercosis cerebral humana. Archivos de Investigación Médica 1975;6:1-12.

${ }^{16}$ Rydzewski AK, Chishelm ES, Kagan IG. Comparison of serologic tests for human cysticercosis by indirect hemagglutination, indirect immunofluorescent antibodies and aga gel precipitin tests. $J$ Parasitol 1975;61:154-5.

${ }^{17}$ Miller B, Goldber MA, Heiner D, Myers A, Goldberg A. A new immunologic test for CNS cysticercosis. Neurology 1984;34:695-7.

${ }^{18} \mathrm{Kagan}$ IG. A review of serological test for the diagnosis of hydratidic disease. Bull WHO 1968;61:154.

${ }^{19}$ Mohammad I, Heiner D, Miller B, Goldberg M, Kagan I. Enzyme-linked immunosorbent assay for the diagnosis of cerebral cysticercosis. J Clin Microbiol 1984; 20:775-9.

${ }^{20}$ Arambulo P, Walls S, Kagan G. Serodiagnosis of human cysticercosis by microplate ELISA. Acta Trop 1978; 35:63-7.

${ }^{21}$ Voller A. Heterogeneous enzyme-immuno-assay and their applications. In: Maggio ET, ed. Enzyme-immunoassays. Boca Raton, Fla: CRC Press, 181-96.

${ }^{22}$ Miller B, Myers A, Goldberg M. Cerebral cysticercosis: diagnosis by a specific IgG antibody. Neurology 1982;32:79.

${ }^{23}$ Bout D, Dugimont J, Farag A, Capron A. Immunodiagnosis of human parasitic disease by the ELISA. Lille Medicalle 1975;20:561-6.

${ }^{24}$ Voller A, Bidwell E, Bartlet. Enzyme immunoassays in diagnostic medicine. Bull WHO 1976;61:154.

${ }^{25}$ Flisser A, Woodhouse, Larralde L. Human cysticercosis; antigens, antibodies and non responders. Clin Exp Immunol 1980;39:27-37.

${ }^{26}$ Yakouleff, Grenhouse V, Flisser A, Sierra A, Larralde C. Analysis of antigenic variation in cysticercosis of taenia solium. J Parasitol 1982;68:39-47.

${ }^{27}$ Flisser A. The Immunology of Human Cysticercosis. Molecules, Cells and Parasites in Immunology. London: Academic Press Inc, 1980:125-43.

${ }^{28}$ Ogilvie BM, Wilson RJ. Evasion of the immune responses by parasites. Br Med Bull 1970;32:177.

${ }^{29}$ Urquhart GM. Immunological unresponsiveness in parasitic infections. J Parasitol 1970;56:547-51.

${ }^{30}$ Sognadares-Bernal F. Immunoglobulins attached to and in the integument of adult schistosoma manson sambon 1907, from first infection of CFI mice. $J$ Parasitol 1976;62:222-6.

${ }^{31}$ Estañol B, Kleriga E, Lombardo L, Loyo M. Mechanisms of hydrocephalus in cerebral cysticercosis. Implications for therapy. Neurosurgery 1983;13:119-23. 